An attention-based view of family firm adaptation to discontinuous technological change:

Exploring the role of family CEOs' non-economic goals

\author{
Nadine Kammerlander \\ (corresponding author) \\ University of St.Gallen (CFB-HSG) \\ Dufourstrasse 40a \\ CH-9000 St.Gallen \\ nadine.kammerlander@unisg.ch \\ $+41712247116$ \\ Melanie Ganter \\ University of St.Gallen (CFB-HSG) \\ Dufourstrasse 40a \\ CH-9000 St.Gallen \\ melanie.ganter@unisg.ch
}

April 10, 2014

Paper accepted for publication at Journal of Product Innovation Management 


\title{
An attention-based view of family firm adaptation to discontinuous technological change: Exploring the role of family CEOs' non-economic goals
}

\begin{abstract}
Recent studies show that managerial attention is a particularly important precursor of established firms' responses to discontinuous technological change. However, little is known about the factors that shape managerial attention-response patterns. In our qualitative study, we investigate how the attention of family firm CEOs to discontinuous technological shifts, the interpretation and decision making processes associated with these changes, and ultimately organizations' responses are affected by CEOs' non-economic goals. Based on seven longitudinal case studies in the German consumer goods industry, we induce a process model that extends the findings of the literature on the attention-based view and helps to explain heterogeneity in family firms' adaptation to discontinuous technological change. We show that the family CEO's specific non-economic goals - such as power and control, transgenerational value, the maintenance of family reputation, the continuance of personal ties, or personal affect associated with the family business - determine whether the CEO assesses an emerging technology as relevant enough to warrant a reaction from the firm. Moreover, the family CEO's non-economic goals constrain the set of considered responses. The outcome of this sensemaking process determines the organization's response. For instance, in the specific context of this study, the goal of "family power and control" entailed an immediate interpretation of the focal trend as important for maintaining influence, and resulted in an unconstrained set of responses and, ultimately, high innovation in the new domain. Over time, family CEOs might re-evaluate the emerging trend based on their goals and adapt organizational moves accordingly. We identify and discuss how ambiguities and dilemmas may arise during this process. Our findings contribute to the literature on adaptation to discontinuous technological change and to family firm research.
\end{abstract}

Keywords: discontinuous technological change, family firm, attention-based view, non-economic goal, sensemaking, innovation 
Adaptation to discontinuous technological change constitutes one of the most difficult challenges for established organizations (e.g., Christensen and Bower, 1996, Danneels, 2004, Hill and Rothaermel, 2003). Recent research on this topic highlights the protagonist role of cognitiveemotional factors, which can cause incumbents to overlook and misinterpret such radical environmental breakthroughs (e.g., Kaplan and Tripsas, 2008, Tripsas and Gavetti, 2000). In particular, studies have illuminated the effects of top managers' attention (Ocasio, 1997) in the context of discontinuous technological change (e.g., Kaplan, 2008, Maula, Keil and Zahra, 2013, Tripsas and Gavetti, 2000). For instance, Maula et al. (2013) recently showed how network partners affected the attention managers paid to upcoming changes in the information and communication industry and, ultimately, their organizations' adaptations to those changes.

Despite those recent advancements, we still lack knowledge about how one particularly noteworthy but underinvestigated aspect of managerial attention plays out in the context of discontinuous technological change and potentially causes variance in adaptation behavior: the CEOs' sets of non-economic goals (Danneels, 2004) that are known to play a vital role, in particular in family firms (Chrisman, Chua, Pearson and Barnett, 2012), one of the most important organizational types worldwide (Anderson and Reeb, 2003). While an abundant body of literature indicates that organizational actors often pursue various goals (Cyert and March, 1963), the effect of goals other than profitability on CEOs' attention has largely been neglected (cf. Greve, 2008).

In particular, family firm research has long emphasized that family firms pursue noneconomic goals (Chrisman, et al., 2012) beyond economic purposes, as they strive to preserve their socioemotional wealth (Berrone, Cruz and Gomez-Mejia, 2012). Such non-economic goals have been found to substantially affect family firm behavior (Chrisman and Patel, 2012, Gomez-Mejia, Haynes, Nunez-Nickel, Jacobson and Moyano-Fuentes, 2007).

As the CEOs of different family businesses might pursue different non-economic goals (Berrone, et al., 2012), non-economic goals might help explain variance in family firms' adaptations to discontinuous technological change. Although researchers agree that there is 
substantial variance among family firms in general (Zahra, Hayton and Salvato, 2004) and that it is important to study such heterogeneity (Chua, Chrisman, Steier and Rau, 2012), how and why family firms act heterogeneously when confronted with discontinuous technological change remains unclear. Therefore, we aim to answer the following research questions: (1) How does the family CEO's attention to non-economic goals affect his or her sensemaking process and, subsequently, organizational adaptation to discontinuous technological change? and (2) How and why does heterogeneity in family CEOs' non-economic goals lead to heterogeneity in the respective family firms' adaptations to discontinuous technological change?

To answer those questions, we build on seven case studies of German family firms, which allow us to develop an attention-based model (Ocasio, 1997, 2011) of the effect of non-economic goals on family firms' adaptations to discontinuous technologies. Given the large number of family firms around the world and across industries, their substantial impact on the economy (Anderson and Reeb, 2003), and their structural and behavioral idiosyncrasies (König, Kammerlander and Enders, 2013), a more nuanced understanding of how and why family firms adapt to discontinuous technological changes is crucial for understanding technology adaptation and family firm behavior.

Our study contributes to the extant literature in three ways. First, we contribute to the research on discontinuous technological change (e.g., Christensen, 2006, Danneels, 2004) by revealing how non-economic goals of key decision makers can act as barriers or enablers of organizational adaptation to discontinuous technological change.

Second, we contribute to research on family businesses. In this regard, this study is one of the first to integrate Ocasio's seminal concept of the attention-based view $(1997,2011)$ into family business research and to use it to explain the organizational behavior of family firms. In particular, we show how family CEOs' differences in underlying values and motivations, which can be linked to dimensions of socioemotional wealth (Berrone, et al., 2012, Gómez-Mejía, Cruz, Berrone and Castro, 2011), result in heterogeneity of adaptation patterns among family firms. 
Third, we contribute to the ongoing discussion on innovation in family businesses (see De Massis, Frattini and Lichtenthaler, 2013 for an overview). In the last decade, scholars have become increasingly interested in explaining the particularities of innovativeness in family firms. This stream of research shows that family firms vary in their innovation input (i.e., R\&D intensity) depending on intra-family conflicts (Block, 2010), the family's risk propensity (Munari, Oriani and Sobrero, 2010), and firm performance (Chrisman and Patel, 2012). However, with few exceptions (Bergfeld and Weber, 2011, König, et al., 2013), the context of discontinuous technologies has been largely overlooked. Moreover, while we have deep knowledge of the input and output variables that explain innovation in family firms, we lack a profound understanding of the innovation processes in those firms, especially of why family businesses choose to engage in certain innovation activities (De Massis, Sharma, Chua and Chrisman, 2012). Our insights are also relevant for practitioners, as we raise awareness of non-economic goals and highlight their consequences. Moreover, we provide several examples of how family firms can master the challenges posed by discontinuous change.

In the following, we will first outline extant literature on discontinuous technological change, attention, and non-economic goals in family firms before describing our qualitative research approach. Subsequently, we present our overall model, describe the individual cases, and compare them in a cross-case analysis. We conclude by discussing our results.

\section{THEORETICAL FRAMEWORK}

\section{Adaptation to Discontinuous Technological Change and the Attention-based View}

Discontinuous technologies, which are frequently labeled as "disruptive" or "radical," are defined as technological innovations that deviate non-paradigmatically from the previous productdevelopment trajectory (Christensen and Bower, 1996, Hill and Rothaermel, 2003). Such innovations typically possess radically new features, involve fundamentally new processes, and/or are based on new business models (König, Schulte and Enders, 2012). Frequently cited examples of discontinuous technologies include minicomputers (Christensen and Bower, 1996), biopharmaceuticals (Kaplan, Murray and Henderson, 2003), and digital photography (Tripsas, 
2009). In many cases, discontinuous technologies are first commercialized by new entrants before being adopted by incumbent firms (Christensen and Bower, 1996). Many (but not all) established organizations experience difficulties in adopting such discontinuous technologies and often react with inertia, particularly in the early phases of technology development (Danneels, 2004, Tushman and Anderson, 1986). Due to numerous economic, emotional, and cognitive reasons (Hill and Rothaermel, 2003), such organizations may react late (Miller and Friesen, 1980), with low resource commitment (Christensen, 1997), with low stamina (König, et al., 2013), or with insufficient reconfigurations of internal routines (Gilbert, 2005).

Scholars have long sought to explain heterogeneity in organizational adaptation to discontinuous technological change (Maula, et al., 2013, Mitchell, 1989). In recent years, research has increasingly focused on applying cognitive perspectives to explain organizational decision making and adaptation behavior (e.g., Hammedi, Van Riel and Sasovova, 2011, Kaplan, 2008, Tripsas, 2009). One particularly interesting research stream in this field is the attention-based view (Ocasio, 1997, 2011). The attention-based view predicts that attention structures within firms, together with other important precursors, such as the environment and intra-organizational communication channels, affect the sets of "issues and answers" considered by decision makers. The (limited) sets of relevant issues and potential answers, in turn, affect organizational moves, and hence adaptation.

The antecedents of attention structures as determinants of organizational adaptation have recently started to gain scholarly attention (Eggers and Gerasymenko, 2013, Gerstner, König, Enders and Hambrick, 2013, Maula, et al., 2013). The values and beliefs of “players," especially CEOs (Hambrick, 1994, Ocasio, 1997) who have the authority and power to influence organizational decision making, are essential components of the firm's attention structure (Danneels, 2004). In an effort to understand the role of values and beliefs in organizational decision making, past research pointed to the important role of the firm founder's imprint (Baron, Hannan and Burton, 1999, Tripsas and Gavetti, 2000) and has revealed that, over time, senior managers 
develop a unique set of beliefs that is based on a shared legacy within the firm (Prahalad and Bettis, 1986). Our study adds to these initial insights by exploring how differences in decision makers' goals that are caused by variation in decision makers' values and beliefs about the purpose of their firms create variance in how discontinuous technological changes are interpreted and responded to. We focus on CEOs as key players as they are known to possess substantial discretion to affect firm behavior (Finkelstein and Hambrick, 1990), especially when they belong to the owning family (Chua, Chrisman and Sharma, 1999, Schulze, Lubatkin and Dino, 2003).

\section{Family Businesses and Dimensions of Non-Economic Goals}

Family businesses are the dominant type of business worldwide (La Porta, Lopez De Silanes and Shleifer, 1999). In Germany, for instance, family businesses account for more than ninety percent of all firms (Gottschalk, Hauer, Niefert, Keese and Licht, 2011). In our study, we build on the work of Chua, Chrisman, and Sharma (1999), who refer to the owning family's vision and commitment to the firm as the "essence" that renders family businesses distinguishable from other firms.

In a further investigation into the "essence" of family firms, Gomez-Mejia et al. (2007) found that family firms are distinct from other forms of businesses because of their stock of socioemotional wealth (SEW), and their desire to keep or even increase their SEW in the future ${ }^{1}$. "Socioemotional wealth" refers to the non-economic value that individuals can derive from owning a firm over an extended period of time (Berrone, et al., 2012, Berrone, Cruz, Gómez-Mejía and Larraza-Kintana, 2010, Gómez-Mejía, et al., 2011, Gomez-Mejia, et al., 2007). As such, research on SEW corresponds to studies that have long emphasized the importance of non-economic goals in family firms (Chrisman, et al., 2012, Chrisman, Chua and Sharma, 2005, Corbetta and Salvato, 2004, Sharma, 2004). These non-economic goals co-exist with economic goals, such as achieving certain profitability, where the latter set of goals has received ample attention (cf. Greve, 2008).

\footnotetext{
${ }^{1}$ Other attempts to categorize family firm behavior are, for instance, Miller and Le Breton-Miller's (2005) 4Cframework or Carney's 3P model (Carney, M. (2005). Corporate Governance and Competitive Advantage in FamilyControlled Firms. Entrepreneurship Theory \& Practice 29(3), 249-265. ) In this study, we decided to build on SEW dimensions as categorization, because this allows us to capture the goals of the family CEOs in the best way.
} 
Consistent with research on SEW, the non-economic goals of family firm owners can be categorized along five dimensions (Berrone, et al., 2012, Gómez-Mejía, et al., 2011). First, family members desire to exert power and control over the company and its strategic decision making (Carney, 2005, Chua, et al., 1999). In fact, scholars argue that family members often strive to influence not only their firm but entire social ecosystems, such as industries and communities (Corbetta and Salvato, 2004, Tagiuri and Davis, 1996). Second, family members aim to maintain transgenerational value by keeping the business within the family over several generations (Chua, et al., 1999, Zellweger, Kellermanns, Chrisman and Chua, 2012). In this regard, extant research on family firms emphasizes that owners of family firms tend to strive for intra-family succession in order to ensure that the firm remains infused with family values (Berrone, et al., 2012, Sirmon and Hitt, 2003). Third, family members aim to protect the family's reputation in society (Berrone, et al., 2012). As members of owning families typically identify with their businesses (Zellweger, Eddleston and Kellermanns, 2010), they feel that the firm's reputation reflects onto themselves (Berrone, et al., 2010). They therefore become sensitive about the firm's external image (Micelotta and Raynard, 2011). Fourth, family members aim to preserve close and enduring ties within and around their firm (Miller and Le Breton-Miller, 2005). Family firms often place great emphasis on demonstrating solidarity with their employees (Uzzi, 1997) and on creating relational trust (Coleman, 1988) with non-family constituents, such as customers (Miller, Lee, Chang and Le Breton-Miller, 2009). Finally, members of family firms typically enjoy emotions and affect associated with the family firm (Berrone, et al., 2012). In other words, they often feel emotionally attached to their firm, its history, and its products (Tagiuri and Davis, 1996).

Non-economic goals have been shown to affect various strategic outcomes, such as investments in environmental protection (Berrone, et al., 2010) and family firms' innovation behavior (De Massis, et al., 2013). For instance, Chrisman and Patel (2012) empirically show how the existence of SEW influences the family firms' reference points and thereby affects their R\&D spending. König et al. (2013) argue that the family firm's focus on command, continuity, 
community, and connections (Miller and Le Breton-Miller, 2005) can constrain the resources and capabilities available in the family firm and, ultimately, lead to inertia. More specifically, those authors argue that family firms invest less intensively, less flexibly, yet more persistently into the adoption of discontinuous technologies, as compared to their non-family counterpart (König, et al., 2013). However, those authors do not address heterogeneity among family firms. Moreover, most extant studies on non-economic goals have aimed to directly link non-economic goals to organizational behavior without exploring important linkages with attention and sensemaking.

\section{METHODOLOGY}

\section{Research Design and Setting}

Given the limited extant knowledge about how and why non-economic goals affect adaptation processes, we applied an inductive, case-based approach (Yin, 1994) in order to build mid-range theory (Merton, 1968). This research design is particularly appropriate for our study, as we aim to shed light on sensemaking, which we define in our context as the process of recognizing and interpreting changes in the environment, resulting in a decision of whether and how to react (Gioia and Chittipeddi, 1991, Thomas, Clark and Gioia, 1993). Moreover a qualitative research design is applicable as we aim to answer questions of "how" and "why" rather than "what" or "how many" (Yin, 1994).

Our research setting is the German consumer goods sector, a mature industry that has recently been challenged by digitization through the rapid development of (Internet-based) software and hardware technologies. This digitization represents a wide-ranging and important discontinuous change, and it has brought about two important technological paradigm shifts ${ }^{2}$ (e.g., Christensen and Raynor, 2003, Danneels, 2004, Gilbert, 2005, Jelassi and Enders, 2008). First, consumer products have increasingly been enhanced with electronic features. Second, online business models and e-commerce portals have started to replace traditional shops and, in some cases, even

\footnotetext{
${ }^{2}$ These changes rendered previous core competencies, such as deep knowledge of physical store setups and localized services, obsolete and replaced them with a need for new capabilities. With regard to retailing, firms had to learn how to promote their shops online, adopt dynamic pricing, and instantly react to online customer queries. With regard to production, companies had to use new materials, such as software and hardware, in order to manufacture electronically enhanced products, which required them to acquire new IT skills. Moreover, firms had to adapt to the significantly shorter lifecycle of electronic products.
} 
disintermediated the value chain. In the early phases of this technology cycle, which lasted until the mid-2000s in Germany and which constitute the main focus of this paper, only technologyinterested customers valued digitized products and sales channels. By the time of writing this study (2013), the new technology had become mainstream in most sectors. In fact, turnover in the German online retail segment was expected to reach EUR 29.5 billion in 2012, which represents a 13\% increase from 2011 (Deutscher Handelsverband, 2013).

Our setting provides a unique context for the study of family firms' responses to discontinuous technological changes because the emergence of digitization is sufficiently distant in time to enable us to observe longitudinal response patterns but recent enough to minimize the retrospective bias. Moreover, family firms represent a crucial cornerstone of the focal industry. As suggested in the literature (Eisenhardt, 1989, Glaser and Strauss, 1967), we build on a theoretical sample of seven established businesses in the German consumer goods sector that vary in terms of size, age, and reaction to the discontinuous technological change. Appropriate firms were identified using information available on the Internet and data provided by industry associations. All seven family businesses were led by a family CEO of at least the second generation throughout the emergence of the discontinuous technology. Each company was fully owned by one family, which significantly influenced the organization's culture and values. All interviewees confirmed that they viewed their businesses as "family firms." The final sample of firms is shown in Table 1.

Insert Table 1 around here

\section{Data Collection}

The challenge of our research setting was obtaining reliable, longitudinal data that captured not only hard facts regarding the family firms' implementation activities but also reflections of the family CEOs' latent sensemaking with regard to the discontinuous technological change. To overcome this challenge, we relied on two main data sources: personal interviews (mainly undertaken in 2010) and the historic websites (from the mid-1990s to 2012) of the respective firms (see Table 1).

Our analysis of the firms' historic websites helped us to overcome the retrospective bias that 
often challenges studies, especially studies of privately owned firms. Information gathered from websites provided empirical evidence of when and how firms launched their first products based on the new technology and, in some cases, information on how they interpreted the ongoing developments in the industry. In order to retrieve this data, we used "Waybackmachine" to systematically access the websites of each company in at least two-year steps (from 1996 to 2012). We browsed through all of the websites' contents (including sub-sites), with a particular focus on sections such as “About Us," "Our Products and Services," "News," and "Press Releases."

In addition, we collected interview data in order to gather information on the sensemaking of the family CEOs and to better understand the details of the firms' adaptation processes. We conducted 28 open-ended, mostly in-person interviews with CEOs, employees, and industry experts based on semi-structured templates ${ }^{4}$. Each interview lasted from 30 minutes (employees) to 150 minutes (CEOs, close advisors, and industry experts). As suggested in the extant literature (e.g., Bechhofer, Elliott and McCrone, 1984), the interviews were conducted by two interviewers, ${ }^{5}$ audio recorded, and transcribed verbatim shortly after the interview.

Most important were the interviews with the family CEOs and/or their close advisors. These interviews revealed the CEOs' attention to specific non-economic goals, as well as their sensemaking processes, which resulted in decisions whether and how to adopt the discontinuous technology. Such data is difficult to gather in any other way. Additional interviews with employees aimed to triangulate statements made by the CEOs regarding organizational routines and family influence, whereas interviews with industry experts enhanced our understanding of industry norms. In addition to the two main data sources, we used other data sources to triangulate our findings such as secondary data (e.g., company brochures, books, catalogs, and press articles from a 15-year timeframe) and observations (e.g., store or company visits).

\section{Data Analysis}

In line with Eisenhardt's (1989) eight-step process for building theory based on cases, we iteratively

\footnotetext{
${ }^{3}$ A free service offered by Internet Archive (http://www.archive.org).

${ }^{4}$ Additional information on the data collection and data analysis process of this study can be found in the supplementary online Appendix.

${ }^{5}$ The only exception was interviews with employees, which were conducted by phone with only one interviewer.
} 
engaged in the data gathering and analysis process, thereby integrating a variance and a process perspective (Langley, 1999). First, for each company, we summarized the findings of the datacollection process into a case study that described the respective company, its key stakeholders, the CEO's sensemaking, and the firm's adaptation process over time. Based on empirical evidence ("first-order data") from these case studies, we engaged in a data-reduction process (Miles and Huberman, 1994) to distill higher-order constructs, which we later linked to the extant literature.

In a subsequent step, we conducted a cross-case analysis, searching for common patterns among the cases. To do so, we created an initial coding scheme for the higher-order constructs identified in the first step based on extant research on family businesses as well as literature on organizational adaptation. We then coded the textual material while iteratively refining the coding schemes. We used the computer programs NVivo and Excel to organize our data and to code the interviews. In line with best practices in case-study research (Bechhofer, et al., 1984, van Maanen, 1979), our coding and analysis process was undertaken by multiple coders who independently coded and interpreted the data. After gathering the independent perspectives of the individual coders, we examined the independent findings, triangulated them with additional secondary data when available, and discussed any remaining discrepancies until consensus was reached. Graphical illustrations of the findings and Excel-based overview charts were particularly useful in our evaluation process. We presented preliminary results to experts and interviewees and used their feedback to make refinements to the individual cases and the model (Flick, 2009).

\section{RESULTS}

In line with predictions found in theory on family business (Berrone, et al., 2012, Gomez-Mejia, et al., 2007), our results indicate that our case-study family CEOs possessed high levels of socioemotional endowment, which they aimed to maintain and/or enhance. Furthermore, qualitative coding and frequency counts reveal that the family CEOs referred to non-economic goals more 
often than economic goals during the interviews ${ }^{6}$. The total counts and the proportion of references to economic versus non-economic goals were relatively stable among the cases. However, the specific non-economic goals that the family CEOs pursued varied substantially among the firms. In the following, we introduce the process model of family firm adaptation to discontinuous technological change that we induced from our case-based evidence.

\section{An Attention-Based Model of Family-Firm Adaptation to Discontinuous Technologies}

The overarching model that we induced from our data is visualized in Figure 1. This model builds on the attention-based view (Ocasio, 1997) to explain how the non-economic goals of family firm CEOs shape the sensemaking of these players and, in turn, the organizational responses of the respective firms to discontinuous technological changes.

\section{Insert Figure 1 around here}

The process begins with the emergence of a discontinuous technology (in our specific case: digitization), which is introduced by industry-external firms (Hill and Rothaermel, 2003) and thus can be classified as a stimulus that is external to the entire industry. After recognizing the discontinuous technological change, the family CEO makes sense of it. In a first stage he or she determines whether the discontinuous technology is perceived as relevant or irrelevant (Christensen and Bower, 1996), and whether it requires instant action (Tripsas and Gavetti, 2000, Tushman and Anderson, 1986). The family CEO's initial interpretation of this discontinuous technology is thereby shaped by the CEO's goals, especially his or her attention to non-economic aims (arrow a).

The outcome of this initial assessment of the new technology affects what the CEO considers as viable options for initial organizational response (arrow b). If several non-economic goals (or different aspects of one non-economic goal) lead to diverging interpretations of the issue, ambiguity regarding the trend's relevance arises. This, in turn, makes the CEO uncertain about how to best respond to the discontinuous change (arrow c). In addition, the CEO's non-economic goals can

\footnotetext{
${ }^{6}$ This is particularly the case for the early phase of technology emergence (roughly until mid-2000s in our context). In this early phase, economic incentives to invest in digitization were low, particularly for profitable and well-established firms active in the traditional consumer goods sector.
} 
either restrict his or her set of possible responses or liberate the CEO from economic constraints associated with organizational moves (arrow d). In certain circumstances a dilemma arises that slows down the entire sensemaking process (arrow e). This is the case if a family CEO who interprets the discontinuous technological change as highly relevant can only choose from a limited set of possible responses (because of the limits imposed by his or her non-economic goals) when addressing the issue (cf. König, et al., 2013). The sensemaking process ends with the family CEO's initial decision whether and how to respond to the discontinuous technological change (arrow f).

Over time, the CEO re-engages in the sensemaking process. This is necessary as the further technological development and the initial organizational moves affect the family CEO's economic and non-economic endowments, which might prompt the CEO to re-prioritize the goals. Such reengagement in the sensemaking process might lead to changes in the adaptation pattern (arrow g).

\section{Individual Case Studies}

In the following, we describe our seven case studies, which we ordered along the five noneconomic goals introduced in the theoretical overview. We provide evidence of the respective family CEOs' interpretation of and the firms' reactions to digitization (first level data), which we gathered from multiple sources. We also link the cases to the various second- and higher order constructs covered by our model.

Anything \& More — Attention on the family's power and control. Anything \& More is a large organization that is fully owned by the second generation of the founding family. As we synthesized from interview statements, Jake, the family CEO, is particularly inclined to maintain the family's power within and outside of the firm as the following evidence illustrates. The focus on family control within the firm is, for instance, reflected in the family CEO's leadership motto:

We know the business. Our father built the business. ...- - we define the direction we will take.

Evidence of this focus is also found in a historical anecdote. In the second half of the twentieth century, the firm's founder had to sell shares to outside investors, i.e., another family. This move

\footnotetext{
${ }^{7}$ All names of firms and individuals have been changed to ensure confidentiality. Unless otherwise indicated, the information presented in these case studies stems from our analysis of interview material.
} 
"made the family CEO very unhappy," according to those close to the family. After more than two decades, Jake succeeded in buying back those shares. In so doing, he secured the family's power within the firm. Today, the family "categorically refuses to consider any possibility of going public," according to a close advisor of the family CEO.

However, the CEO's attention on power and control is not restricted to the firm itself as the following evidence shows. A commemorative publication from 2009 described the family members as individuals who aimed to "leave a distinct, unmistakable mark on the German economy." The same brochure described both the founder and his son, Jake, as being characterized by "stubbornness, ... willpower, ... and the desire to assume responsibility"-A description that can be associated with the goal to exert power and control.

Jake's goal of exerting power and control also affects strategic decision making within the firm, as the following evidence shows. Although Anything \& More is a large company with a topmanagement team that formally has the power to jointly decide on strategic actions, all proposals for strategic activities must be discussed with and approved by Jake. This requirement makes Jake the de facto sole decision maker. A close advisor of the family CEO stated in the interview:

\begin{abstract}
Before a proposal is discussed at a board meeting, the initiators of the proposal go to the CEO and say: "At the next board meeting, we would like to discuss the following topic." The CEO then has a look and responds: ... "That is good. I like it." or "No, I do not like it. We should do it differently." ... In the latter case, the topic is removed from the agenda. One must rework the concept until the CEO likes it. However, once the CEO says "Yes, I like it," the board meeting takes place in the following way. One introduces the concept during the board meeting. ... Then it becomes dead silent in the room, so that you can hear the rustling of the air conditioner. After this pause, the CEO says "I believe it is a good idea. We should follow your proposal." Subsequently, the voices [of top-management team members] are heard saying "Yes, I think so, too." Ultimately, the board's decision is unanimous.
\end{abstract}

Stage one and two: Initial interpretation of the issue and considered responses. According to our interviews, Jake recognized the emergence of digitization as a new technology when the American trend was first discussed in German newspapers in the mid-1990s. Press articles of that time and interview statements reveal that Jake perceived the new technology as an "opportunity [to enlarge the family's] empire" and thus apparently as a useful means to increase his family's power over the German market. Jake's positive attitude towards digitization and the timeliness of his assessment of digitized services as relevant for his business are noteworthy, because investments in digitization 
were initially perceived as unprofitable within the German market. For instance, German journalists assessed the chances of the new technology to turn out successful as uncertain, and they foresaw profound challenges in adopting the new technology, as articles in renowned magazines such as Spiegel in 2000 reveal. In fact, at that time, Jake had a somewhat conservative outlook on the likely amount of revenues that could be derived from digitization within the next decade, as he stated in several media interviews. He envisaged digitization as a powerful "accessory [that would, however,] never have the potential to replace traditional business." In other words, economic considerations fail to convincingly explain Jake's positive attitude towards digitization at the time.

The set of strategic options that Jake considered after he assessed the new technology as an important and urgent issue was relatively unconstrained, as shown by interview quotes such as:

We had a pragmatic view and said: "The Internet is something new and we have to offer an online shop now. ... Maybe there will be concepts that differ from today's core concepts. [When considering this new business area, there was] a substantial amount of imagination among us.

This pragmatic view of how to pursue the e-commerce business indicates that Jake's set of potential responses to the discontinuous technological change was relatively unconstrained by any economic or non-economic considerations. This apparent lack of restrictions was confirmed by one of the managing directors, who stated in a 2009 press interview that Anything \& More's core business "would remain [only] as long as it was useful."

Stage three: Initial organizational moves. The outcome of Jake's sensemaking process, that is, the perception of digitization as relevant, urgent issue that needed to be responded to with any possible move, facilitated quick and fundamental organizational changes as analyses of web archives and interviews show. From the very beginning, Anything \& More invested substantial resources in the commercialization of the new business, as a manager described:

We started proactively by setting up a completely new division, which we called "New Media." We hired [Andy] as the director and gave him a substantial budget that allowed him to make bold moves. ... Moreover, we brought in Dr. [Endres] ... from a successful player in the field of digitization. He had the task of building up our e-commerce solution, as we said: "Okay, we really have to tackle this now."

Anything \& More's initial adoption activities included the launch of a series of online shops beginning in 1994, but these shops failed due to a lack of customer interest. These failures did not demotivate the family CEO, who viewed the setbacks as "steps toward gaining experience in e- 
commerce." Apparently, the family CEO's focus on power and influence freed him from economic constraints, such as required profitability. Therefore, the company continued investing, although "most projects ended up in the Internet's chamber of horror," as one interviewee stated. Over time, according to our interviews, the firm built up comprehensive knowledge and capabilities within the new domain by, for instance, hiring managers and employees who were experienced in ecommerce, and by acquiring external knowledge through new ventures.

Stage four: Temporal development. Over a span of two decades, Anything \& More persistently showed high levels of innovativeness based on the new technology as press releases and website statements reveal. It established a venture-capital organization to invest in promising Internet start-ups. It was the first German player in this market to offer native e-commerce services, and it experimented with online shopping through mobile devices as early as 2002 (according to press releases and interview statements). This continuous stream of investments indicates that Anything \& More did not experience a fundamental re-evaluation phase. Instead, it maintained its initial decision to profoundly invest in digitization. Interview statements and press material indicate that the non-economic goal of preserving power and control was reinforced by economic considerations as the new technology advanced in maturity, because at that time, Jake began to perceive digitization as an "increasingly important strategic determinant of success," according to a press interview at the turn of the century.

King's Goods-Attention on transgenerational values. King's Goods is a large family firm that has been owned and managed by members of a single family since its foundation almost 150 years ago. It is led by George, the family CEO. Although the company is similar in size to Anything \& More and active in similar segments, George's most salient non-economic goal is different. As he discussed in an informal conversation with another family business owner in 2013, George is most conscious of "being able to transfer the business to [his] children-regardless of the size of that business." Although this goal assumes that the business will remain financially viable over time, it is likely to be distinct from pure attention on economic factors and from the non-economic goal of 
familial power, mostly because this goal engenders a prolonged time horizon. Instead of considering what is good for the business today, George's attention is centered on what would be good for the business in 30 years, as stated in a press article in 2010. According to our interview with George, this attention on transgenerational values is rooted in the company's heritage and was included in the family constitution. In our interview, George explained that these transgenerational values had been "implanted" in him in his childhood when he joined his father on business trips.

Stage one and two: Initial interpretation of the issue and considered responses. The attention on the next generation affected how the CEO interpreted the emergence of digitization. Similar to Anything \& More's CEO, George recognized the upcoming trend when he read newspaper articles in the early 1990s, according to the interview. However, he began to better understand the importance of the trend when interacting with his children:

I have kids and, of course, they possess all the gadgets that have come onto the market in recent years. ... At first, I thought "This is just a temporary trend." ... But then I realized that this generation uses technology to differentiate itself from previous generations ... [and that the new technology] would not disappear. ... I could have continued for another ten years [without adoption] and afterwards handed over the business to the next generation. But then, in 10 to 20 years, my children, or my nephews and nieces would have said to me: "Didn't you realize that something was happening? Why didn't you react?"

Apparently, George feared that a non-reaction would jeopardize the sustainability of the firm. Thus, the focus on transgenerational value led him to assess the technology as a relevant challenge to which the firm needed to respond. However, while George interpreted the trend as important, he did not feel the need to engage in instant and profound investment activities. Rather, he intended to:

... keep my options open [because e-commerce is] a fascinating world, which is not easy at all; a world that is highly transparent, incredibly fast, and direct. ... When this world arrives, I want my family business to take part.

When thinking of possible ways to "take part" in this new world, George, similar to Jake, did not place any restrictions on the adoption approach as long as it enabled him to transfer the business to his children, as the following interview quote illustrates:

[Activities that would put the transfer to the next generation at risk] are out of question. We would rather do less but do it sustainably.

This broad view on potential business activities was also evident in the firm's previous activities, which had not been subject to any boundaries in terms of geography, or products and services. 
Stage three: Initial organizational moves. As George comprehended the importance of the discontinuous technological change for himself and his family firm long before it was economically viable (see discussion in respective paragraphs of Anything \& More), King's Goods undertook its first experiments with digitization as early as 1997 (according to archival websites, press releases, and interviews). Those early attempts, which included the introduction of online ordering and homedelivery services in selected regions, were carried out in cooperation with external partners (archival websites). Moreover, these investments were characterized as having a "life in the shadows" (CEO, interview) rather than as bold moves. In fact, the first fully functional Internet shop was not launched until 2001. George reflected on those early activities:

We were too fainthearted — not revolutionary enough. [We ran the shop] as an add-on [only. ...] But I had the feeling that something was going on and that we had to stay attuned to it. ... I may have made one of my better decisions, if I may say so myself, because I did not sell the online shop to [one of our competitors] when I sold the division [to which the online shop belonged]. Instead, I said to myself: "You should keep the online store for now."

Stage four: Temporal development. As the technology moved into the mainstream in the mid2000s, economic interests increased and seemingly also affected George's sensemaking. He subsequently evaluated digitization as an increasingly pressing issue and felt that his firm "had to speed up" its reaction to the technological change (according to interview statements). As expressed in the interview and triangulated with archival web data and annual reports, King's Good subsequently ramped up investments, established a new division, hired external managers, started to co-invest in Internet startups, and launched an additional online shop in 2003 together with a partner. From 2006 to 2009, the number of employees working on digitization doubled (according to annual reports). Despite the intensity of these responses, experts assess the adaptation moves of King's Goods as mimicry of existing business models and as investments in external ventures rather than signs of internal innovation.

Power Star-Attention on family reputation. Power Star is a medium-sized firm owned by its founding family. The family CEO Tim is particularly attentive to maintaining his family's reputation in society as a value-driven family renowned for a focus on social responsibility, quality 
assurance, and innovation as the following evidence reveals. In the interview, Tim particularly stressed the social responsibility of his family as he stated that:

I am liable here. I have a social responsibility! [In other words,] I have not only a financial responsibility but also a social responsibility.

Related to this perceived social responsibility is Tim's desire to be known to provide excellent and innovative products and services to his customers. This is, for instance, reflected in the wealth of “excellence” certificates and quality awards shown on Power Star's websites (archival and current), which indicate that the family pays a significant amount of attention to conveying an honorable and reliable image to customers. Moreover, according to Tim, Power Star invested in building up a larger-than-financially-reasonable R\&D department in order to provide novel products in the best achievable quality. Although initiatives that improve product quality might at first sight be assessed as part of an (economically motivated) premium supplier strategy, Power Star's investments in such initiatives and certificates exceeded what would be rational from an economic standpoint. For instance, in 2012, Power Star invested more than one million EUR into launching a permanent, regional exhibition about the family firm and an associated illustrated book about the family firm's history (according to press articles). Tim explained in an interview with local media: "We did not invest into those activities in order to earn money."

Stage one and two: Initial interpretation of the issue and considered responses. As Tim explained in the interview, he frequently visited trade fairs to quickly become aware of and get inspired by new trends and ideas that started to emerge. As such, he recognized the ongoing technological changes in the environments in the mid-1990s (according to our interview and triangulated by press releases). Since he interpreted the issue as urgent and relevant_-"at that time people started talking about digitization everywhere," as he described in our interview—he set up a multidisciplinary team of employees that subsequently met on a regular basis to discuss how to integrate the discontinuous technology into Power Star's portfolio of offered products and services. Given Power Star's focus on "being modern” (interview with CEO), non-adoption would have most likely challenged his family's reputation as an innovative player. 
However, as with most discontinuous technologies, digitization was also widely associated with some quality challenges at that time (e.g., delayed deliveries of online-ordered Christmas presents in 1999 in Germany or the poor experience associated with early e-books). These challenges stood in opposition to Power Star's focus on quality, as explained by Tim in the interview: "We wanted to offer only digitized products of highest quality standards." Accordingly, Tim's set of potential responses to this issue was restricted. For instance, as explained in the interview, he only considered products that could be developed in-house in order to ensure that management could monitor all processes and that any potential moves would be prepared carefully in order to secure the quality of his products and services (and thus the family's reputation). Along these lines, the CEO explained:

[We aimed to] thoroughly assess the [potential] concepts [because the new technology] was something completely new to us [and] something fairly complex. ... In such circumstances, there is a lot to take into account. You have to test so much-it is incredible. ... The only way that we can go into such a situation is to prepare everything very carefully. It does not matter whether this takes a bit longer. We will save the time afterwards. Preparation is a highly essential element.

Although Power Star's capabilities regarding the implementation and commercialization of the new technology might be assessed as (at least) comparable to those of Anything \& More and King's Goods from the outsider's perspective, the latter two companies adopted a trial-and-error mode rather than contemplating potential challenges related to the technology's adoption in advance. According to Tim, the firm's internal preparation phase lasted from the mid-1990s until 2001, when the family CEO, after ample testing and training, was finally convinced that the firm could offer digitized products and services at the desired level of quality and the development phase began.

Stage three: Initial organizational moves. In order to implement this response, Power Star had to make significant upfront investments. Accordingly, the development of digitized products and services started in 2001 and they were made available to customers in 2004 (archival websites, firm chronicle). In order to mitigate the risk of quality issues that could harm the family's reputation, all development was carried out in-house. For that purpose, a new department was created, externals were hired, and employees were trained (interview). The CEO explained: 
We hired [digitalization specialists] from outside the company. We built an entire department from scratch. We need these employees a lot now ... and we need a lot of technical equipment to be able to do these things. There is so much more to it.

Stage four: Temporal development. After the launch of its first electronic products and services, Power Star continually refined its digitized portfolio (according to several press notes). However, customer feedback and news reports indicate that the firm did not have to revise its strategy because the new products and services successfully met quality demands. Although the company adopted the existing technology instead of inventing fundamentally new solutions, the firm improved the quality and reliability of products and services in the new domain (according to archival websites and press releases). Such activities could be categorized as incremental innovations in the new domain. ${ }^{8}$ Given this apparently satisfactory outcome of his firm's response to the discontinuous technological change, Tim seemed to have no reason to alter his adaptation strategy, which might explain the firm's so far stable adaptation pattern.

Retail 2000-Attention on enduring ties. Retail 2000 is a large family-owned and familymanaged firm that was founded almost 200 years ago. Since its foundation, the family has spent a significant amount of effort and time on building up and maintaining good relationships with its stakeholders, especially customers and employees (according to interview statements, press releases, and statements on the firm's current and archival websites). For instance, the announcement indicating the establishment of the firm, which was released in the early nineteenth century, emphasized Retail 2000's focus on employee satisfaction and wellbeing. The most recent version of the website highlights "customer orientation [...and] employees" as main pillars.

While fostering ties with important stakeholders can also be a defining element of an economically driven strategy (for instance, due to expected benefits from customer loyalty), Retail 2000's focus on maintaining those ties seems to go beyond what is financially beneficial. For example, a few decades ago, Retail 2000's CEO had the financially attractive opportunity to substantially enlarge the business by opening the first large discount store in the region. As Michael, the family CEO, explained, his father, who was CEO at the time, initially decided against

\footnotetext{
${ }^{8}$ At the time when Power Star started to implement the new technology, digitization was already established enough to allow for incremental innovation based on existing products and services.
} 
taking the economically attractive offer, as he feared that such a store would disrupt the region's infrastructure and harm the family's personal relationships with suppliers and local competitors. Furthermore, in 2012, Retail 2000 still offered selected, economically unprofitable products in its portfolio that were only desired by several long-standing niche customers. As Michael explained:

We also stock items that only a few customers buy. However, we know that these products are important for those customers because they cannot get them anywhere else.

This statement shows that Michael is particularly attentive to the needs of loyal customers. It also suggests that his primary rationale for offering such products is to preserve his family firm's ties to the company's long-term customers.

Stage one and two: Initial interpretation of the issue and considered responses. Michael first encountered the upcoming technology in newspaper articles at the end of the 1990s, according to the interview. As Michael was mainly focused on his (local) network of established ties, he initially assessed the new technology as having little relevance for his own business as the following quote illustrates:

We viewed pure e-commerce — by that, we mean selling things online and delivering them to the customers — as peripheral. ... Retail is a local business.

Michael's interpretation of the issue as having little relevance differs from those evaluations made in the above-described family firms and instead is likely to resemble the perception of a CEO purely driven by economic goals. Given Michael's interpretation of the new technology as largely irrelevant, all considered responses were naturally related to strategic moves in the old domain.

Stage three: Initial organizational moves. Retail 2000 did not adopt digitization during its phase of emergence. Instead, it invested in established markets (with established suppliers and loyal customers). From the beginning of the late 1990s, Retail 2000 invested in opening new stores in selected regions, to which family members or trusted employees were personally attached (according to interview statements and archival websites). It also expanded its product portfolio to include goods from local suppliers who were also part of the family's network. In general, the aim in this regard was to improve the customer's experience, according to the interview. Many of those activities could be labeled as incremental innovations in the old domain. 
Stage four: Temporal development. As the technology developed further, Michael began to realize its importance, most likely because he began to view it as a threat to his transgenerational intentions, as described below. In the interview, which took place in 2011, the CEO stated that his assessment of the technology had changed within the last years:

It is obvious that e-commerce is an important field today. We do not need any consultative study to tell us that. If you read a newspaper or look at the Internet, you can easily see that. [... However,] we have not seen a way to get there yet. [We thus require] new ideas. ... [We feel torn between] being loyal to [existing, local] customers and thereby hazarding our sustainability [or entering new markets. We need to find a long-term solution.] This long-term orientation includes development processes, so that we work really hard in precisely the fields we feel are important for us, and we make sure that we make progress in those fields.

This re-assessment happened at a time when firms with purely economic motives were also more likely to have recognized the importance of the new technology. However, while large parts of the traditional German retailing market were already struggling to deal with the development of ecommerce, as data from industry associations shows, Retail 2000 did not experience an immediate economic threat. Performance data obtained from the Orbis (Bureau van Dijk) database show continual sales growth from $2006^{9}$ to 2012 . Furthermore, an investigation by a German business magazine reveals that Michael's family was able to increase its wealth by several hundred million EUR between 2001 and 2012. This indicates that the perceived "hazard [of] sustainability", as it was described by Michael, was most likely tied to the long term and to Michael's desire to hand over a vital business, prepared for long-term success, to his children. The focus on this noneconomic goal of transgenerational value became more salient over the first decade of the $21^{\text {st }}$ century as the entry of Michael's son (who became a manager within the firm in 2012) approached.

As the statement above illustrates, Michael's focus on local customers and his reluctance to implement any activities that would not be beneficial for those stakeholders constrained his set of available actions. Akin to Power Star's CEO, Michael therefore faced a dilemma when he recognized the issue of digitization as relevant but was constrained by the limited set of possible responses. This dilemma was apparently resolved towards the end of 2011 when Retail 2000 entered the e-commerce market by launching a service that combined online ordering with physical collection at the nearest store. This business model, which already existed on the market,

\footnotetext{
${ }^{9}$ No public data on turnover is available for periods before 2006 for this firm.
} 
constituted a "compromise" or "hybrid" solution. It allowed the firm to (partly) adopt the technology while maintaining its connections with local customers.

White \& Blue-Attention on enduring ties. White \& Blue was established in the early twentieth century, and it is still fully owned by the founder's family. Today, the company is managed by Richard, a family CEO. Evidence from the interviews, websites, and press releases shows that the family CEO, similar to the owners of Retail 2000, pays close attention to maintaining good relationships with stakeholders, especially employees and customers. This is not only mirrored in the company's mission to "provide home" for customers and employees, but also in the large number of events organized by the owning family for employees.

Stage one and two: Initial interpretation of the issue and considered responses. Similar to Retail 2000's CEO, Richard first assessed the emerging technology as irrelevant for his firm. ${ }^{10}$

I assumed there was no [disruptive change]. I also believe in evolutionary rather than revolutionary developments: "Retail is Detail."

Presumably, the upcoming trend did not affect any of his focal goals in its early stages of development. However, some long-tenured employees assessed the trend as important and consequently approached the CEO with their ideas for adoption, as Richard explained in the interview. Given the family CEO's focus on trust and self-determination among employees, Richard seemingly felt torn between his own perceptions of digitization and those of his trusted employees and felt ambiguity in how to finally assess the relevance of the new technology. Ultimately, as explained in the interview, he targeted for a "hybrid" strategy that aimed to satisfy both views.

Any potential response to the new technology was constrained by the goal-infused boundary condition that service and personal relations to his customers had to remain unaffected by technology adoption. Richard emphasized this aspect of his most fundamental business philosophy:

Our services must be right. ... Service means being friendly and helpful and other very simple things that have not changed, and probably will not change for many years to come.

As this interview quote indicates, radical e-commerce solutions that relied on computerized rather than human service provision were most likely not included in Richard's set of considered

\footnotetext{
${ }^{10}$ The low relevance of e-commerce is also mirrored in a 200-page firm chronicle, issued in 2008, which contains only two mentions of the term "Internet" (or relevant synonyms).
} 
responses due to his focus on interpersonal relations with customers.

Stage three: Initial organizational moves. In addition to initiatives to strengthen its position in established markets, such as the launch of various customer-retention programs, White \& Blue engaged in some low intensity activities in the e-commerce domain starting in 1999. For example, it began to offer online photo development, home delivery of flowers ordered online, and "order online - pick up from the nearest store" services for certain geographical areas (interviews and archival websites). According to the CEO and archival websites, whenever such initiatives failed, ecommerce was quickly abandoned resulting in an "on-off" pattern of technology adoption.

Stage four: Temporal development. After years of ambiguity of how to interpret digitization, around 2010, Richard seemingly began to realize that the trend of digitization would continue:

[E-commerce and digitization] might change a lot. ... I believe or, maybe, I hope that social interactions will not be replaced by computers, iPhones, or iPads. ... We have to think of another way [to adopt e-commerce]. However, we know that we cannot get away without building on the new technology. I would say that this has become certain over the years. I was really the one who was most hesitant, but I am very clear now: we also have to follow this path.

Most likely, this re-evaluation was triggered by economic reasons. Over time, economic incentives to invest into the new technology had increased and according to the Orbis database, White \& Blue faced severe economic struggles beginning in 2006. White \& Blue launched a new e-commerce shop in mid-2011 by mimicking already existing solutions according to press releases. This online shop offered some of the products sold in White \& Blue's shops but not the entire product portfolio. Moreover, the online shop was clearly separated from the firm's core business. For instance, there was no Internet link from the company's website to the newly launched online shop and there were no marketing initiatives in the classic, physical stores to promote the new business. This "partial" move into the new domain, which did not seek to harvest all synergies between the domains, can be interpreted as a reflection of the CEO's ongoing ambiguity regarding digitization.

Top Goods-Attention on emotions and affect. Top Goods was founded almost 200 years ago, and it is now led by two members of the owning family. Many interview statements indicate that the CEO pays close attention to maintaining the positive emotions related to the firm in the present. Moreover, the CEO frequently referred to words related to the firm's legacy such as 
“tradition," "ancestors," and "pre-determination." Other, more future oriented economic and noneconomic goals appear to play subordinate roles as the analysis of interview statements revealed. For instance, showing no growth aspirations, John stated in the interview, "I think, in principle, we will always stay a small player." John, the family CEO described his own path to becoming CEO of the family firm and his motivation to work for Top Goods ${ }^{11}$ as follows:

From early on, my parents pushed me in the direction of becoming their successor. After an apprenticeship, I joined the family firm at the lowest level and had to climb up the greasy pole. ... I have to conclude that I am happy and proud to work in this family firm.

Stage one and two: Initial interpretation of the issue and considered responses. As with White \& Blue and Retail 2000, John initially assessed digitization as irrelevant for his firm. The focus on affect, joy, and tradition as most important endowments of John, stood in sharp contrast to the new technology, which was downplayed as the following cite shows:

Electronic devices are not communicative. ... I thus believe that there will be room for our firm in the future-at least as long as computers do not start to show any emotions. ... This is our right to exist. [Our products and services] bring relief in a digitized world. ... I think we should continue working on [our traditional products and services]. If we are not able to do so, we should close our business.

This attitude was also shared by his co-CEO, as a 2004 interview with media revealed. Given this assessment of the issue as not particularly relevant for the firm and the resulting limited scope of strategic action ("continue working on [our traditional products and services]"), Top Goods did not attempt to adopt the new technology.

Stage three and four: Initial organizational moves and temporal development. In the mid2000s, Top Goods began investing into broadening its traditional product portfolio, especially by focusing on premium products, addressing new customer groups, and moving into international markets (according to interviews and archival websites). These moves could be explained as reaction to economic challenges, which even threatened Top Goods' organizational health: The sales volume declined by 50\% between 2000 and 2012 in two of Top Goods' core segments, according to archived websites. Although several of these activities were assessed as "highly innovative" by industry experts, none of them crossed the technological boundary.

\footnotetext{
${ }^{11}$ Although he is emotionally attached to the firm and its history, John does not feel a specific attachment to the consumer goods segment. He rather feels attached to the tradition of the firm. In the interview, John explained that he would have wanted to become a mechanical engineer, if there was no family business.
} 
Peter's Finest-Attention on emotions and affect. The case of Peter's Finest, a mediumsized, third-generation family firm, can be viewed as a literal replication of the Top Goods case. In both cases, the goals of the family CEO, and the sensemaking and adaptation process are similar. The CEO of Peter's Finest quickly decided not to adopt the new technology. Peter's Finest moved into a market niche to escape the need to adopt the technological change and invested in domain offense activities in this specific niche. Within this market niche, Peter's Finest is now known for its innovativeness as the family CEO, our interviewee, proudly explained. ${ }^{12}$

\section{Cross-case Summary}

In the following, we show how our process model explains adaptation heterogeneity among family firms by comparing the CEOs' sensemaking and firm behavior at each stage of the induced model across cases. The results of our cross-case comparison are shown in Table 2.

Insert Table 2 around here

Attention to non-economic goals. Our case-based evidence revealed that the seven family CEOs differed considerably with regards to their non-economic goals. Moreover, we found that each noneconomic goal affected the firms' adaptation, particularly in the early phases of sensemaking.

Stage one: Issue interpretation. Synthesizing the findings of our individual cases shows that the CEOs' interpretations were highly heterogeneous within our sample. Three of the seven CEOs interpreted the technology as relevant early on. Two of those CEOs even viewed the discontinuous change to be of pressing importance. In contrast, four CEOs initially felt that the emerging technology was irrelevant for their businesses.

This heterogeneity arose because the interpretation of the issue was influenced by the family CEOs' specific non-economic goals (arrow a). Family CEOs appeared to interpret the emergent trend as relevant from the very beginning - and even earlier than one might expect them to do if they

\footnotetext{
${ }^{12}$ Additional information on this case can be obtained from the authors.
} 
had followed purely economic goals ${ }^{13}$ — if the new technology was assessed as useful for achieving their non-economic goals. This was the case for the goal of exerting "power and control" (Anything \& More) because the CEO hoped to find ways of further influencing the industry and increasing his family's power. Family CEOs with goals of creating "transgenerational value" (King's Goods) or being renowned as owners of innovative, high-quality firms (Power Star) interpreted the new technology as relevant because they feared that non-adoption would jeopardize their non-economic goals. In contrast, family CEOs initially assessed the technology as irrelevant if their non-economic goals were "unaffected" by the new technology, that is, if adoption of the new technology would not help to achieve non-economic goals, nor would non-adoption put those goals directly at risk. The CEOs who paid most attention to protecting “enduring ties" with stakeholders (Retail 2000, White \& Blue) and those CEOs focused on the family's "emotions and affect" (Top Goods, Peter's Finest) concentrated on trends and issues within the old domain. This outcome is similar to the sensemaking predicted for purely economically driven firms at early stages of technology evolution (when the technology is likely to be considered unprofitable). We also observed that one CEO who focused on "enduring ties" (White \& Blue) was confronted with ambiguity about how to assess the new technology: his own assessment of digitization as irrelevant to achieve the non-economic goal of “binding ties" was incompatible with his trusted employees' assessment of digitization as relevant. As the CEO typically paid great attention to the opinion of trusted employees (due to the goal of "binding ties"), he was uncertain how to treat the issue and his interpretation of the relevance of the technology was unstable over time (arrow c).

Stage two: The set of considered responses. As the CEOs' interpretations of the issue affect their sets of considered answers (Ocasio, 1997), we also observed heterogeneity in the CEOs' contemplations of how to respond to the new technology (arrow b). However, the breadth and range of adaptation options varied not only because the interpretations of the issue differed but also because CEOs were dissimilarly constrained or liberated by their non-economic goals (arrow d).

\footnotetext{
${ }^{13}$ Standard literature on discontinuous technologies predicts that firms will only start to assess a new technology as relevant when the masses become interested in that technology.
} 
Among the three firms that immediately perceived the issue as important, the goals of exerting "power and control" (Anything \& More) and maintaining "transgenerational value" (King's Goods) resulted in largely unconstrained sets of responses. Response options were perceived as valuable as long as they were considered useful for achieving the non-economic goals. Thus, a focus on these particular non-economic goals even allowed for more freedom than would be expected if the firm was purely driven by economic factors (and therefore largely constricted to financially profitable projects and restricted from engaging in years of "trial and error").

In contrast, the CEO who focused on the "family's reputation" (Power Star) was largely restricted in his set of potential responses, as any possible response needed to fulfill certain criteria (e.g., high levels of quality, no error policy) that stemmed from this specific goal. Consequently, while the non-economic goal of maintaining the family's reputation motivated the CEO to adopt the new technology (see stage 1), it also restricted his set of possible responses, causing a dilemma that prolonged the firm's sensemaking and preparation phase (arrow e). The set of responses considered by CEOs who focused on "enduring ties" was also highly constrained (White \& Blue, Retail 2000 in later phases), as this goal centered on fulfilling the needs of long-term customers and other stakeholders, and thus inhibited activities that would negatively affect these stakeholders. The two companies focused on "emotions and affect" (Top Goods, Peter's Finest) did not view the technology as relevant throughout our investigation. However, statements made by these CEOs during the interviews indicated that any strategic move by the firm was substantially constrained by their desire to maintain the status quo, and by their reverence of the company's history.

Stage three: Initial organizational moves. As a result of the substantial variance among family firms in their CEOs' sensemaking, the initial organizational moves were largely heterogeneous (arrow f). All three firms that initially viewed the issue as relevant engaged in some distinct form of domain creation (Ford and Baucus, 1987). In the case characterized by a perception of urgency combined with an unconstrained set of responses (Anything \& More), the resulting response pattern was a highly intense and flexible adoption of the new technology, which resulted in high levels of 
innovation in the new domain. Thus, the focus on "power and control" lead to an adoption that was earlier, more intensive, and more flexible than if the firm was purely driven by economic goals. In the case in which the issue was interpreted as relevant but not urgent (King's Goods), early moves to adopt the new technology were characterized by low intensity and could be assessed as mimicry in the new domain. The family CEO that assessed the issue as relevant and pressing yet was restricted to a limited set of possible responses (Power Star), engaged in late but highly intensive adoption. As the $\mathrm{CEO}$ was focused on being an innovative family that cares about quality, the firm engaged in numerous incremental (and thus technologically low risk) innovations in the new domain but shied away from more substantial changes.

The four companies that initially assessed the technology as rather irrelevant concentrated on domain offense. The two companies in which the CEOs focused on "emotions and affect" (Peter's Finest, Top Goods) pushed for innovations in their established domains as being (incrementally) innovative contributed to their "joy" associated with the firm. The firms of those family CEOs with focus on "binding ties" (Retail 2000, White \& Blue) concentrated on implementing successful concepts in the old domain (mimicry in old domain). In addition, while the CEO of White \& Blue viewed the technology as irrelevant, his employees disagreed. Thus, White \& Blue not only engaged in domain offense but also in some cautious, inflexible adoption activities, which mostly copied existing solutions in the new domain and were typically abandoned after a short time span.

Stage four: Temporal development. Following the characteristic development of discontinuous technologies, over time, "digitization" began to become mainstream and it became clear that the new technology would prevail. Thus, contrary to the initial phase that lasted roughly until the mid-2000s, economic considerations started to offer support for adoption of the discontinuous technology. In our case studies, three of the seven firms substantially changed their initially chosen adaptation approach over time (arrow g). For instance, the family firm that prioritized "transgenerational values" (King's Goods) substantially increased its initially rather cautious investment in adoption as the technology became more mainstream and, thus, more 
imperative for preserving the family CEO's economic and non-economic endowments. However, the firm's type of engagement — mimicry of existing solutions — did not change. Similarly, those family firms that focused on "enduring ties" with existing customers were forced to change their strategy due to economic pressure (White \& Blue) as well as the CEO's increased attention on "transgenerational value creation" (Retail 2000). Thus, these CEOs had to find compromise solutions that could align their partly diverging economic and non-economic interests. These compromise solutions can be characterized as mimicry in the new domain, as the firms copied existing adoption approaches. In contrast, those CEOs who prioritized "family reputation" (Power Star) and "power and control" (Anything \& More) did not substantially alter their adaptation strategies, as their initially chosen adaptation approaches were apparently able to continuously satisfy their economic and non-economic goals (arrow g). Finally, we found that those family firms that focused on “emotions and affect” (Top Goods, Peter's Finest) prioritized their (current) joy of working in a traditional family firm over economic considerations. They therefore did not change their strategies throughout the period investigated for this study, even as the technology became more established..

\section{DISCUSSION}

Based on a series of seven case studies of German family firms, we revealed the central role of CEOs' non-economic goals in their sensemaking when discontinuous technologies emerge. As such, our findings contribute to the evolving stream of research that seeks to understand heterogeneity in firms' adaptation to discontinuous technological change (e.g., Gilbert, 2005, Hill and Rothaermel, 2003, König, et al., 2013). In particular, our findings advance knowledge of the cognitive antecedents of organizational adaptation (e.g., Kaplan, 2008, Kaplan and Tripsas, 2008, Maula, et al., 2013, Tripsas, 2009). While the cognitive frames of key players in incumbent organizations are commonly viewed as important precursors for adaptation to discontinuous technological change, the role of non-economic goals in this context has largely remained underinvestigated (Danneels, 2004). This is surprising given the role that such goals play in decision making within family firms (Chrisman, et al., 2012, Chrisman, et al., 2005, Corbetta and 
Salvato, 2004, Sharma, 2004, Ward, 2004) and given that this type of organization dominates economies worldwide (Anderson and Reeb, 2003). Notably, the existence of non-economic goals is not bound to family influence. For instance, a thirst for personal power, political opinion, or ideological beliefs might affect sensemaking and decision making among CEOs. Depending on the CEOs' level of managerial discretion, such factors may, in turn, ultimately affect organizational moves in other types of organizations.

Moreover, our findings extend the general literature on attention and sensemaking (Ocasio, 1997, 2011, Weick, 1995), as our model complements previously presented frameworks by introducing the effects of non-economic goals. In addition, we provide empirical insights into how various dilemmas and ambiguities (Weick, 1995) resulting from the incongruence of simultaneous goals shape sensemaking processes and, potentially, affect or hamper decision making. In line with Ocasio (1997) and Selznick (1984), as well as recent research in the family business literature (Chrisman and Patel, 2012, Gomez-Mejia, et al., 2007), we show that some non-economic goals are indeed at odds with the company's economic health. For instance, in the specific context we studied, a focus on emotions and affect can result in inertia (König, et al., 2013). However, other non-economic goals, such as a desire for power and control or a desire for transgenerational value transfer, might lead to a timely recognition of the ongoing trend and thereby be beneficial for the achievement of economic goals in the medium and long term. Given the specific context of discontinuous technological changes, such non-economic goals are likely to be well aligned with economic ones in later phases of development, and they might be mutually reinforcing.

Furthermore, our findings emphasize the iterative character of attention, sensemaking, and adaptation processes. While various studies have highlighted the importance to study managerial attention over time (e.g., Kaplan, 2008, Maula, et al., 2013), it remains unclear how top managers' attention changes and what triggers such a change. Our analysis provides some initial insights into how the salience of goals over time (e.g., as succession approaches or the economic evaluation of 
technologies changes) leads to a re-evaluation of issues and answers that might, in turn, result in altered organizational moves.

Several major contributions of this study are related to the family business literature. Family firm research has long emphasized that the non-economic goals of owning families affect decision making and strategic behavior in family businesses (e.g., Chrisman and Patel, 2012, Gomez-Mejia, et al., 2007, Kotlar and De Massis, 2013). However, this research has remained surprisingly silent about the precise mechanisms that link non-economic goals of owning family members to organizational behavior. Our research sheds light on these micro-processes by revealing how noneconomic goals can affect key decision makers' perceptions of emerging challenges, the set of considered responses, and subsequent organizational moves. The integration of research on attention with the family business literature thus appears to be a promising path towards a better understanding of family firm behavior, especially with regard to the role of non-financial goals. Therefore, the application of our model might not be limited to the context of discontinuous technological change. It may also be relevant in other contexts that require attention of decision makers, such as institutional changes (Nigam and Ocasio, 2010) or mergers and acquisitions (Yu, Engleman and Van de Ven, 2005).

In addition, our results highlight the need to differentiate among the specific non-economic goals pursued by CEOs of owning families. This is important, as our results show that different aspects of non-economic goals might lead to substantial deviations in organizational behavior (see Table 2). We therefore complement recent empirical observations of goal diversity within family firms (Kotlar and De Massis, 2013) by shedding light on the consequences of goal heterogeneity.

Related to the heterogeneity of non-economic goals in family firms is the observed heterogeneity in the key decision makers' time horizons. With few notable exceptions (e.g., Chrisman and Patel, 2012), research has paid little attention to variations in the time horizons of family firms. This is surprising, as some evidence indicates that family firms adopt a long-term focus (e.g., Le Breton-Miller and Miller, 2006), while other studies suggest that family firms focus 
on the short-term maximization of socioemotional wealth (e.g., Gomez-Mejia, et al., 2007). Our empirical results may serve as initial evidence that specific non-economic goals are associated with certain time horizons. For instance, in our sample, a focus on emotions and affect was associated with short-term planning horizons, whereas a focus on transgenerational values was associated with time horizons of up to 30 years.

Our study also contributes to the ongoing discussion on innovation and technology adaptation in family firms (e.g., Carnes and Ireland, 2013, De Massis, et al., 2013). Despite increasing scholarly interest in family firms' adaptation to discontinuous technological change (e.g., Bergfeld and Weber, 2011, König, et al., 2013), our understanding is still incomplete. Previous studies emphasize, for instance, the capabilities and structures of family firms (e.g., Carnes and Ireland, 2013, König, et al., 2013) and the role of family members in terms of being "excellent in managing [radical] innovation" (Bergfeld and Weber, 2011, p. 92) and thus help to understand how family firms differ from non-family firms in terms of adaptation to fundamentally changing environments (König, et al., 2013). We contribute to this literature stream by empirically revealing that there is also substantial heterogeneity of response patterns among family firms and by linking this variance to differences in CEOs' non-economic goals.

One of the goals of this study was to contribute to open the "black box" of technology adoption by revealing not only whether family firms adopt a new technology but also how that adoption process takes place. So far, family business scholars mostly focused on the effects of innovation input and output variables (De Massis, et al., 2013). Our study, however, sheds light on the CEOs' sensemaking processes and identified ambiguities and dilemmas that challenged family firm CEOs under certain conditions. Our findings not only contribute to explaining why family firms do or do not adopt discontinuous technologies but also to explaining how they do it. As outlined in our individual case descriptions and the cross-case analysis, we show that the studied family firms used a broad range of adaptation types, ranging from innovation in the old domain to mimicry in the new domain, as well as different levels of innovations in the new domain. 


\section{LIMITATIONS AND FURTHER RESEARCH}

Despite the above-mentioned contributions, our study has some limitations, many of which are inherent in most qualitative research. First, we cannot rule out that biases in our respondents' reflections affected our research results. Accordingly, one could argue that our focus on few, selected interviewees per company distorted our results. However, this focus is rooted in the nature of our research question - our main goal was to understand the non-economic goals of decision makers that influence their interpretation of a discontinuous technological change and the resulting organizational moves. Given the organizational and hierarchical structures of our sampled firms, those aspects are often only known by the family CEOs, who were our informants. Whenever possible, we triangulated the interview data with information from other sources. Our focus on CEOs is also in line with extant theory that emphasizes the role of leadership in explaining variance in adaptations to discontinuous technological changes (Gerstner, et al., 2013, Tellis, 2006). However, we encourage future research that specifically explores goal diversity within the owning family and its effect on organizational moves in the context of discontinuous change. Collecting responses from the various family members would also shed light on whether respondents speak on behalf of the owning family or whether their statements referred to their individual perceptions.

Moreover, as in most case study research, interview statements referring to past sensemaking processes might be affected by retrospective biases (Gavetti and Rivkin, 2007, Gilbert, 2005). We took two methodological precautions to alleviate this risk. First, when defining the research setting, we deliberately selected an industry in which the discontinuous technology had occurred relatively recently in order to minimize retrospective bias among respondents. Second, we drew on extensive longitudinal primary and secondary material, such as the content of historical websites, press releases, and press articles, to triangulate our data.

Furthermore, researchers working with qualitative data need to be aware of alternative explanations of the observed phenomena and take measures to rule them out (Yin, 1994). Potential alternative explanations in our setting relate to differences in firm size, firm age, product portfolios, 
governance structures, orientation (family versus business), general innovativeness, and CEO characteristics. By being aware of this hazard and by paying particular attention to such factors when conducting the interviews and analyzing the data, we aimed to mitigate the risk that an alternative explanation might serve as a better explanation of the observed phenomena. Future research should nevertheless control for these factors, as for instance, firm size might limit the extent of resources available for adaptation moves.

Moreover, we argued that the discontinuous technology was initially considered unprofitable. We have to acknowledge, however, that an economically driven real options valuation might have encouraged financially driven firms as well as the sampled family firms, which we characterized by initially low adoption intensity, to invest cautiously in the discontinuous technology from early on.

Caution is also required when aiming to transfer our findings to other contexts. While the overall model is likely to be widely applicable, the specific effect of non-economic goals and their alignment with economic goals might substantially depend on the specific context.

We also encourage family business scholars to investigate other elements of the attentionbased view, especially the family firm's procedural and communication channels (Ocasio, 1997). Such investigations would strengthen our understanding of the spatial, temporal, and procedural contexts in organizations that guide decision makers' focus on attention (Stinchcombe, 1987).

\section{MANAGERIAL IMPLICATIONS AND CONCLUSION}

By building on evidence from multiple case studies, we discussed how the non-economic goals of German family firms affected their CEOs' sensemaking and, ultimately, their organizational adaptations to discontinuous technological changes. However, many decision makers in family firms are not fully aware of these goals and their consequences. We show that transparency with regard to the prevailing non-economic goals, and awareness of the consequences for firm strategy and behavior are crucial for any family firm that is facing an emerging discontinuous technological change. Christensen (2006, p. 48) states that "disruption is a relative phenomenon. ... It is a business model problem, not a technology problem.” Given the heterogeneous reactions of family 
firms to discontinuous technological changes despite their initially similar business models, we extend this statement to the following: "It is not only a business model problem. It is also a problem of the CEOs' prevailing goals."

\section{Acknowledgements:}

We express our appreciation to Guest Editor Jess Chua and two anonymous reviewers for their valuable input and suggestions. We also gratefully acknowledge helpful comments from Albrecht Enders, Björn Ivens, Andreas König, Trish Reay, and Thomas Zellweger, as well as comments made by participants at the Family Enterprise Research Conference (FERC) Doctoral Consortium 2012 in Montreal and participants at the Academy of Management Annual Meeting 2013 in Orlando, Florida. Moreover, we thank Mateja Andric, Kilian Bornschein, Philipp Hummel, Ramiya Musayeva, and Barbara Schillo for research assistance. Furthermore, we acknowledge editing support provided by Tina Pedersen. This study partly builds on material collected for the first author's dissertation.

\section{REFERENCES}

Anderson, R.C. and Reeb, D.M. (2003). Founding-family ownership and firm performance: evidence from the S\&P 500. Journal of Finance 58(3), 1301-1328.

Baron, J.N., Hannan, M.T. and Burton, M.D. (1999). Building the iron cage: determinants of managerial intensity in the early years of organizations. American Sociological Review 64, 527548.

Bechhofer, F., Elliott, B. and McCrone, D. (1984). Safety in numbers: on the use of multiple interviewers. Sociology 18(1), 97-100.

Bergfeld, M.M.H. and Weber, F.M. (2011). Dynasties of innovation: highly performing German family firms and the owners' role for innovation. International Journal of Entrepreneurship and Innovation Management 13(1), 80-94.

Berrone, P., Cruz, C. and Gomez-Mejia, L.R. (2012). Socioemotional wealth in family firms: theoretical dimensions, assessment approaches, and agenda for future research. Family Business Review 25(3), 258-279.

Berrone, P., Cruz, C., Gómez-Mejía, L.R. and Larraza-Kintana, M. (2010). Socioemotional wealth and corporate responses to institutional pressures: Do family-controlled firms pollute less? Administrative Science Quarterly 55(1), 82-113.

Block, J.H. (2010). R\&D investments in family and founder firms: an agency perspective. Journal of Business Venturing 27(2), 248-265.

Carnes, C.M. and Ireland, R.D. (2013). Familiness and innovation: resource bundling as the missing link. Entrepreneurship Theory \& Practice 37(6), 1399-1419.

Carney, M. (2005). Corporate governance and competitive advantage in family-controlled firms. Entrepreneurship Theory \& Practice 29(3), 249-265.

Chrisman, J.J., Chua, J.H., Pearson, A.W. and Barnett, T. (2012). Family involvement, family influence, and family-centered non-economic goals in small firms. Entrepreneurship Theory \& Practice 36(2), 267-293.

Chrisman, J.J., Chua, J.H. and Sharma, P. (2005). Trends and directions in the development of a strategic management theory of the family firm. Entrepreneurship Theory \& Practice 29(5), $555-575$. 
Chrisman, J.J. and Patel, P.C. (2012). Variations in R\&D investments of family and nonfamily firms: behavioral agency and myopic loss aversion perspectives. Academy of Management Journal 55(4), 976-997.

Christensen, C.M. (1997). The innovator's dilemma. Boston, MA: Harvard Business School Press.

Christensen, C.M. (2006). The ongoing process of building a theory of disruption. Journal of Product Innovation Management 23(1), 39-55.

Christensen, C.M. and Bower, J.L. (1996). Customer power, strategic investment, and the failure of leading firms. Strategic Management Journal 17, 197-218.

Christensen, C.M. and Raynor, M.E. (2003). The innovator's solution. Boston, MA: Harvard Business School Press.

Chua, J.H., Chrisman, J.J. and Sharma, P. (1999). Defining the family business by behavior. Entrepreneurship Theory \& Practice 23(4), 19-39.

Chua, J.H., Chrisman, J.J., Steier, L.P. and Rau, S.B. (2012). Sources of heterogeneity in family firms: An introduction. Entrepreneurship Theory \& Practice 36(6), 1103-1113.

Coleman, J.S. (1988). Social capital in the creation of human capital. The American Journal of Sociology 94, 95-120.

Corbetta, G. and Salvato, C. (2004). Self-serving or self-actualizing? Models of man and agency costs in different types of family firms: a commentary on comparing the agency costs of family and non-family firms: conceptual issues and exploratory evidence. Entrepreneurship Theory \& Practice 28(4), 355-362.

Cyert, R.M. and March, J.G. (1963). A behavioral theory of the firm. Englewood Cliffs, NJ: Prentice-Hall.

Danneels, E. (2004). Disruptive technology reconsidered: A critique and research agenda. Journal of Product Innovation Management 21(4), 246-258.

De Massis, A., Frattini, F. and Lichtenthaler, U. (2013). Research on technological innovation in family firms: present debates and future directions. Family Business Review 26, 10-31.

De Massis, A., Sharma, P., Chua, J.H. and Chrisman, J.J. (2012). Family business studies: an annotated bibliography. Cheltenham, UK: Edward Elgar Publishing.

Eggers, J.P. and Gerasymenko, V. (2013). Shifting focus: managerial attention dynamics in the venture capital industry. Working Paper available from: http://pages.stern.nyu.edu/ jeggers/Files/Research_EggersGerasymenko.pdf.

Eisenhardt, K.M. (1989). Building theories from case study research. Academy of Management Review 14(4), 532-550.

Finkelstein, S. and Hambrick, D.C. (1990). Top-management-team tenure and organizational outcomes: The moderating role of managerial discretion. Administrative Science Quarterly 35(3), 484-503.

Flick, U. (2009). An introduction to qualitative research. Thousand Oaks, CA: Sage.

Ford, J.D. and Baucus, D.A. (1987). Organizational adaptation to performance downturns: An interpretation-based perspective. Academy of Management Review 12(2), 366-380.

Gavetti, G. and Rivkin, J.W. (2007). On the origin of strategy: action and cognition over time. Organization Science 18(3), 420-439.

Gerstner, W.-C., König, A., Enders, A. and Hambrick, D.C. (2013). CEO narcissism, audience engagement, and organizational adoption of technological discontinuities. Administrative Science Quarterly 58(2), 257-291.

Gilbert, C.G. (2005). Unbundling the structure of inertia: resource versus routine rigidity. Academy of Management Journal 48(5), 741-763.

Gioia, D.A. and Chittipeddi, K. (1991). Sensemaking and sensegiving in strategic change initiation. Strategic Management Journal 12(6), 433-448.

Glaser, B. and Strauss, A. (1967). The discovery of grounded theory: Strategies of qualitative research. London, UK: Wiedenfeld and Nicholson.

Gómez-Mejía, L.R., Cruz, C., Berrone, P. and Castro, J. (2011). The bind that ties: Socioemotional wealth preservation in family firms. The Academy of Management Annals 5(1), 653-707. 
Gomez-Mejia, L.R., Haynes, K.T., Nunez-Nickel, M., Jacobson, K.J.L. and Moyano-Fuentes, J. (2007). Socioemotional wealth and business risks in family-controlled firms: evidence from spanish olive oil mills. Administrative Science Quarterly 52(1), 106-137.

Gottschalk, S., Hauer, A., Niefert, M., Keese, D. and Licht, G. (2011). Die volkswirtschaftliche Bedeutung der Familienunternehmen. Stiftung Familienunternehmen (ed.). München, Germany.

Greve, H.R. (2008). A behavioral theory of firm growth: sequential attention to size and performance. Academy of Management Journal 51(3), 476-494.

Hambrick, D.C. (1994). Top management groups: a conceptual integration and reconsideration of the "team" label. Research in Organizational Behavior 16, 171-171.

Hammedi, W., Van Riel, A.C.R. and Sasovova, Z. (2011). Antecedents and consequences of reflexivity in new product idea screening. Journal of Product Innovation Management 28(5), 662-679.

Hill, C.W. and Rothaermel, F.T. (2003). The performance of incumbent firms in the face of radical technological innovation. Academy of Management Review 28(2), 257-274.

Jelassi, T. and Enders, A. (2008). Strategies for e-business. Harlow, UK: Prentice Hall.

Kaplan, S. (2008). Cognition, capabilities, and incentives: Assessing firm response to the fiber-optic revolution. Academy of Management Journal 51(4), 672-695.

Kaplan, S., Murray, F. and Henderson, R. (2003). Discontinuities and senior management: assessing the role of recognition in pharmaceutical firm response to biotechnology. Industrial and Corporate Change 12(2), 203-233.

Kaplan, S. and Tripsas, M. (2008). Thinking about technology: Applying a cognitive lens to technical change. Research Policy 37(5), 790-805.

König, A., Kammerlander, N. and Enders, A. (2013). The family innovator's dilemma: how family influence affects the adoption of discontinuous technologies by incumbent firms. Academy of Management Review 38(3), 418-441.

Kotlar, J. and De Massis, A. (2013). Goal setting in family firms: goal diversity, social interactions, and collective commitment to family centered goals. Entrepreneurship Theory \& Practice 37(6), 1263-1288.

La Porta, R., Lopez De Silanes, F. and Shleifer, A. (1999). Corporate ownership around the world. Journal of Finance 54, 471-517.

Langley, A. (1999). Strategies for theorizing from process data. Academy of Management Review 24(4), 691-710.

Le Breton-Miller, I. and Miller, D. (2006). Why do some family businesses out-compete? Governance, long-term orientations, and sustainable capability. Entrepreneurship: Theory \& Practice 30(6), 731-746.

Maula, M., Keil, T. and Zahra, S. (2013). Top management's attention to discontinuous technological change: corporate venture capital as an alert mechanism. Organization Science 24(3), 926-947.

Merton, R.K. (1968). Social theory and social structure. New York, NY: Simon and Schuster.

Micelotta, E.R. and Raynard, M. (2011). Concealing or revealing the family? Corporate brand identity strategies in family firms. Family Business Review 24(3), 197-216.

Miles, M.B. and Huberman, A.M. (1994). Qualitative data analysis: an expanded sourcebook (2nd ed.). Thousand Oaks, CA: Sage.

Miller, D. and Friesen, P.H. (1980). Momentum and revolution in organizational adaptation. Academy of Management Journal 23(4), 591-614.

Miller, D. and Le Breton-Miller, I. (2005). Managing for the long run: Lessons in competitive advantage from great family businesses. Boston, MA: Harvard Business Press.

Miller, D., Lee, J., Chang, S. and Le Breton-Miller, I. (2009). Filling the institutional void: the social behavior and performance of family versus non-family technology firms in emerging markets. Journal of International Business Studies 40(5), 802-817.

Mitchell, W. (1989). Whether and when? Probability and timing of incumbents' entry into emerging industrial subfields. Administrative Science Quarterly 34(2), 208-230. 
Munari, F., Oriani, R. and Sobrero, M. (2010). The effects of owner identity and external governance systems on R\&D investments: a study of Western European firms. Research Policy 39(8), 1093-1104.

Nigam, A. and Ocasio, W. (2010). Event attention, environmental sensemaking, and change in institutional logics: an inductive analysis of the effects of public attention to Clinton's health care reform initiative. Organization Science 21(4), 823-841.

Ocasio, W. (1997). Towards an attention-based view of the firm. Strategic Management Journal 18, 187-206.

Ocasio, W. (2011). Attention to attention. Organization Science 22(5), 1286-1296.

Prahalad, C.K. and Bettis, R.A. (1986). The dominant logic: a new linkage between diversity and performance. Strategic Management Journal 7(6), 485-501.

Schulze, W.S., Lubatkin, M.H. and Dino, R.N. (2003). Exploring the agency consequences of ownership dispersion among the directors of private family firm. Academy of Management Journal 46(2), 179-194.

Selznick, P. (1984). Leadership in administration: a sociological interpretation. Princeton, NJ: University of California Press.

Sharma, P. (2004). An overview of the field of family business studies: current status and directions for the future. Family Business Review 17(1), 1-36.

Sirmon, D.G. and Hitt, M.A. (2003). Managing resources: linking unique resources, management, and wealth creation in family firms. Entrepreneurship Theory \& Practice 27(4), 339-358.

Stinchcombe, A.L. (1987). Constructing social theories. Chicago, IL: Chicago University Press.

Tagiuri, R. and Davis, J. (1996). Bivalent attributes of the family firm. Family Business Review 9(2), 199-208.

Tellis, G.J. (2006). Disruptive technology or visionary leadership? Journal of Product Innovation Management 23(1), 34-38.

Thomas, J.B., Clark, S.M. and Gioia, D.A. (1993). Strategic sensemaking and organizational performance: linkages among scanning, interpretation, action, and outcomes. Academy of Management Journal 36(2), 239-270.

Tripsas, M. (2009). Technology, identity, and inertia through the lens of "the digital photography company". Organization Science 20(2), 441-460.

Tripsas, M. and Gavetti, G. (2000). Capabilities, cognition and inertia: Evidence from digital imaging. Strategic Management Journal 21, 1147-1161.

Tushman, M.L. and Anderson, P. (1986). Technological discontinuities and organizational environments. Administrative Science Quarterly 31(3), 439-465.

Uzzi, B. (1997). Social structure and competition in interfirm networks: the paradox of embeddedness. Administrative Science Quarterly 42, 35-67.

van Maanen, J. (1979). Reclaiming qualitative methods for organizational research: A preface. Administrative Science Quarterly 24(4), 520-526.

Ward, J.L. (2004). Growing the family business: special challenges and best practices. Family Business Review 10(4), 323-337.

Weick, K.E. (1995). Sensemaking in organizations. Thousand Oaks, CA: Sage.

Yin, R.K. (1994). Case study research. Thousand Oaks, CA: Sage.

Yu, J., Engleman, R.M. and Van de Ven, A.H. (2005). The integration journey: an attention-based view of the merger and acquisition integration process. Organization Studies 26(10), 1501-1528.

Zahra, S.A., Hayton, J.C. and Salvato, C. (2004). Entrepreneurship in family vs. non-family firms: a resource-based analysis of the effect of organizational culture. Entrepreneurship Theory \& Practice 28(4), 363-381.

Zellweger, T., Eddleston, K. and Kellermanns, F.W. (2010). Exploring the concept of familiness: introducing family firm identity. Journal of Family Business Strategy 1(1), 54-63.

Zellweger, T., Kellermanns, F., Chrisman, J. and Chua, J. (2012). Family control and family firm valuation by family CEOs: the importance of intentions for transgenerational control.

Organization Science 23(3), 851-868. 


\section{TABLES AND FIGURES}

Table 1-Case Data

\begin{tabular}{|c|c|c|c|c|c|c|c|c|c|c|}
\hline \multirow{2}{*}{$\begin{array}{l}\text { Company } \\
\text { Anything \& More }\end{array}$} & \multicolumn{4}{|c|}{ Main activities; age; generation; size } & \multicolumn{2}{|l|}{ Interviews } & \multicolumn{2}{|l|}{ Web archive } & \multicolumn{2}{|l|}{ Additional data } \\
\hline & \multicolumn{4}{|c|}{$\begin{array}{l}\text { Consumer good products and retail (non-food); } 100 \% \text { family owned; } 2 \text { nd generation; employees: > } \\
10.000 \text {; }\end{array}$} & \multicolumn{2}{|c|}{2 internal Directors } & \multicolumn{2}{|l|}{2012} & \multicolumn{2}{|c|}{$\begin{array}{l}\text { Press releases 2002-2012, press articles; } \\
\text { festschrift }\end{array}$} \\
\hline King's Goods & \multicolumn{4}{|c|}{$\begin{array}{l}\text { Consumer good products and retail (food and non-food); } 100 \% \text { family owned; } 5 \text { th generation; } \\
\text { employees: }>10.000\end{array}$} & \multicolumn{2}{|l|}{$\begin{array}{l}\text { Family CEO; } \\
\text { CFO }\end{array}$} & \multicolumn{2}{|c|}{$\begin{array}{l}2000,2002,2004,2006,2008 \\
2010,2012\end{array}$} & \multicolumn{2}{|c|}{$\begin{array}{l}\text { Annual reports and press releases 2002- } \\
\text { 2012; store visit, press articles }\end{array}$} \\
\hline Power Star & \multicolumn{4}{|c|}{ Consumer good products and retail (non-food); 100\% family owned, 3rd generation; employees: $\sim 600$} & \multicolumn{2}{|l|}{ Family CEO } & \multicolumn{2}{|c|}{$\begin{array}{l}1999,2000,2002,2004,2006 \\
2008,2010,2012\end{array}$} & \multicolumn{2}{|c|}{ Annual report 2010, press articles } \\
\hline Retail 2000 & \multicolumn{4}{|c|}{$\begin{array}{l}\text { Consumer good products and retail (food and non-food); } 100 \% \text { family owned, } 5 \text { th generation; } \\
\text { employees: }>10.000\end{array}$} & \multicolumn{2}{|c|}{$\begin{array}{l}\text { Family CEO; } \\
\text { Head of communication }\end{array}$} & \multicolumn{2}{|c|}{$\begin{array}{l}1999,2002,2004,2006,2008 \\
2010,2012\end{array}$} & \multicolumn{2}{|c|}{ Store visit, press articles, Orbis } \\
\hline White \& Blue & \multicolumn{4}{|c|}{$\begin{array}{l}\text { Consumer good products and retail (food and non-food); } 100 \% \text { family owned, } 3 \text { rd generation; } \\
\text { employees: } \sim 2.000\end{array}$} & \multicolumn{2}{|c|}{ Family CEO } & \multicolumn{2}{|c|}{$\begin{array}{l}1998,2000,2002,2004,2006 \\
2008,2010,2012\end{array}$} & \multicolumn{2}{|c|}{$\begin{array}{l}\text { Book on White \& Blue's organizational } \\
\text { history; store visit, press articles, Orbis }\end{array}$} \\
\hline Top Goods & \multicolumn{4}{|c|}{ Consumer good products and retail (non-food); $100 \%$ family owned; 4 th generation; employees: $\sim 200$} & \multicolumn{2}{|l|}{ Family CEO } & \multicolumn{2}{|c|}{$\begin{array}{l}2000,2002,2004,2006,2008 \\
2010,2012\end{array}$} & \multicolumn{2}{|c|}{ Product brochure, press articles } \\
\hline Peter's Finest & \multicolumn{4}{|c|}{ Consumer good products and retail (non-food); 100\% family owned; 4th generation; employees: $\sim 50$} & \multicolumn{2}{|l|}{ Family CEO } & \multicolumn{2}{|c|}{$\begin{array}{l}\text { 1997, 1998, 2000, 2002, 2004, } \\
\text { 2006, 2008, 2010, 2012 }\end{array}$} & \multicolumn{2}{|l|}{ Press articles } \\
\hline Not case specific & \multicolumn{4}{|c|}{ Experts (industry experts, other family business owners, family business consultants) } & \multicolumn{2}{|l|}{18} & $\mathrm{n} / \mathrm{a}$ & & Several industry and $\mathrm{m}$ & narket outlooks \\
\hline Sum & & & & & 28 & & 67 & & & \\
\hline & & & Table & 2-Cross-case & alysis & & & & & \\
\hline Dimension & Anything \& More & King's Goods & Power Star & Retail 2 & & & ite \& Blue & Top Goods & Peter's Finest & Economic case \\
\hline Center of Attention & Power and Control & Transgenerational Value & Family Reputation & Enduring Ties & & Enduring & & Emotion and Affect & tEmotion and Affect & Economic goals \\
\hline $\begin{array}{l}2^{\text {nd }} \text { stage: CEO's } \\
\text { Initial Set of } \\
\text { Responses } \\
(\text { arrows } b \& d)\end{array}$ & largely unconstrained & largely unconstrained & $\begin{array}{l}\text { substantially constrained } \\
\text { by desired family } \\
\text { reputation; dilemma due } \\
\text { to misalignment to } \\
\text { interpretation (arrow e) }\end{array}$ & $\begin{array}{l}\text { substantially constrai } \\
\text { avoid disruption of tie }\end{array}$ & lby desire to & $\begin{array}{l}\text { substantia } \\
\text { desire to a }\end{array}$ & $\begin{array}{l}\text { constrained by } \\
\text { id disruption of ties }\end{array}$ & $\begin{array}{l}n . a . \\
\text { (constrained to } \\
\text { status quo) }\end{array}$ & $\begin{array}{l}\text { n.a. } \\
\text { (constrained to status } \\
\text { quo })\end{array}$ & $\begin{array}{l}\text { constrained to } \\
\text { financial } \\
\text { profitability }\end{array}$ \\
\hline \begin{tabular}{|l|}
$3^{r d}$ stage: Initial \\
Organizational \\
Moves (arrow $f$ )
\end{tabular} & $\begin{array}{l}\text { early domain creation, } \\
\text { with high intensity and } \\
\text { flexibility; substantial } \\
\text { innovation in new } \\
\text { domain }\end{array}$ & $\begin{array}{l}\text { early domain creation, with } \\
\text { low intensity; mimicry in } \\
\text { new domain }\end{array}$ & $\begin{array}{l}\text { late domain creation, with } \\
\text { high intensity; } \\
\text { incremental innovation in } \\
\text { new domain }\end{array}$ & $\begin{array}{l}\text { domain offense activit } \\
\text { old domain }\end{array}$ & ; mimicry in & $\begin{array}{l}\text { domain off } \\
\text { (mimicry); } \\
\text { creation ( }\end{array}$ & $\begin{array}{l}\text { se activities } \\
\text { w intensity; domain } \\
\text { micry) }\end{array}$ & $\begin{array}{l}\text { domain offense } \\
\text { activities; } \\
\text { innovation in old } \\
\text { domain }\end{array}$ & $\begin{array}{l}\text { domain offense } \\
\text { activities and } \\
\text { retrenchment into } \\
\text { niche; innovation in } \\
\text { old domain }\end{array}$ & domain offense \\
\hline $\begin{array}{l}4^{\text {th }} \text { stage: Temporal } \\
\text { Development } \\
\text { (arrow g potentially } \\
\text { stimulate additional } \\
\text { cycle }(s) \text { through } \\
\text { model) }\end{array}$ & \begin{tabular}{|l} 
positive evaluation: \\
continuance of initial \\
adaptation pattern \\
"learning of failure"
\end{tabular} & $\begin{array}{l}\text { re-evaluation: } \\
\text { increased attention on } \\
\text { economic goals generates } \\
\text { perception of urgency; } \\
\text { increased intensity of } \\
\text { adoption }\end{array}$ & $\begin{array}{l}\text { positive evaluation: } \\
\text { continuance of initial } \\
\text { adaptation }\end{array}$ & $\begin{array}{l}\text { re-evaluation: } \\
\text { increased attention on } \\
\text { transgenerational val } \\
\text { interpretation as reler } \\
\text { dilemma due to misal } \\
\text { answers (arrow e); st } \\
\text { creation (mimicry) }\end{array}$ & $\begin{array}{l}\text { leads to } \\
\text { t and urgent; } \\
\text { ment to set of } \\
\text { of domain }\end{array}$ & $\begin{array}{l}\text { re-evaluat } \\
\text { increased } \\
\text { goals lead } \\
\text { relevant al } \\
\text { dilemma d } \\
\text { set of ansu } \\
\text { increased }\end{array}$ & $\begin{array}{l}\text { ?: } \\
\text { ention on economic } \\
\text { o interpretation as } \\
\text { urgent; } \\
\text { to misalignment to } \\
\text { s (arrow e); } \\
\text { ensity of adoption }\end{array}$ & \begin{tabular}{|l|} 
positive \\
evaluation: \\
continuance of firm \\
activities
\end{tabular} & $\begin{array}{l}\text { positive evaluation: } \\
\text { continuance of firm } \\
\text { activities }\end{array}$ & $\begin{array}{l}\text { re-evaluation: } \\
\text { economic goals } \\
\text { lead to } \\
\text { interpretation as } \\
\text { relevant and } \\
\text { urgent; domain } \\
\text { creation }\end{array}$ \\
\hline
\end{tabular}


Figure 1-A Model of Family Firm Adaptation to Discontinuous Technologies

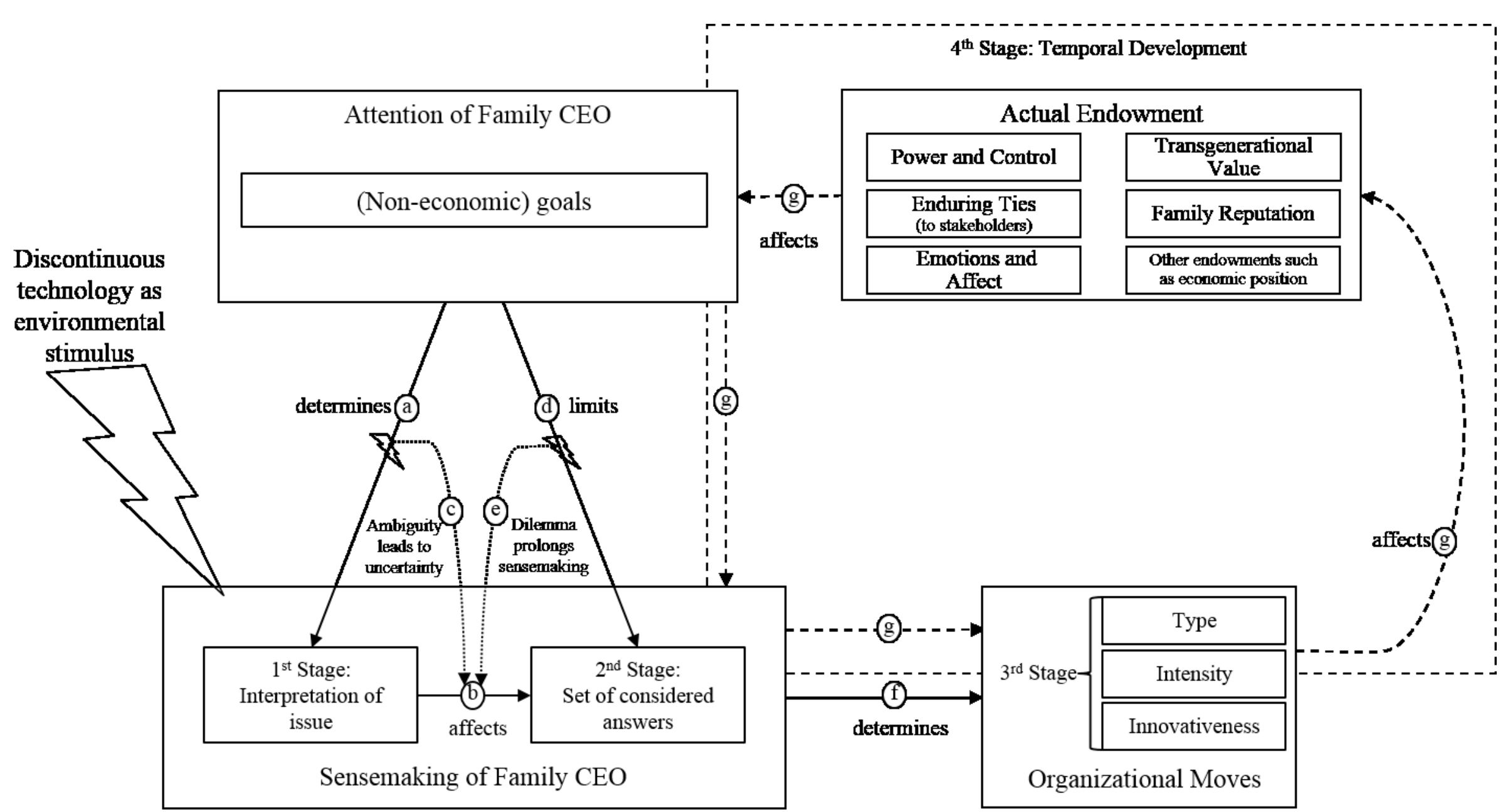

